\title{
JOURNAL.RU
}

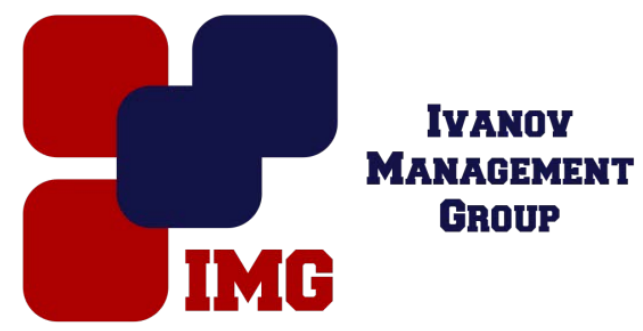

Пушкарева Н.А., Васылева-Керян О.В. Донбасская национальная академия строительства и архитектуры Макеевка, Украина

doi: 10.18411/lj-28-02-2017-2-12

idsp 000001:lj-28-02-2017-2-12

\section{Направления реформирования кадрового обеспечения органов местного самоуправления г. Донецка}

\section{Аннотация}

В статье выявлены основные проблемы кадрового обеспечения местного самоуправления г. Донецка, определены основные направления реформирования кадровых вопросов органов публичной власти.

Ключевые слова: кадровое обеспечение, органы местного самоуправления, управление, факторы, законодательные акты, стратегия.

Кадровое обеспечение органов местного самоуправления важный аспект функционирования регионального менеджмента, так как кадры играют ключевую роль в социально-экономическом развитии региона и государства в целом.

В современных условиях кадровое обеспечение органов местного самоуправления г. Донецка представляет собой сложный многофункциональный процесс, состоящий из комплекса действий по набору, подготовке, обучению персонала органов местного самоуправления для решения важных задач регионального менеджмента. Однако этот процесс имеет ряд недостатков и нуждается в существенном реформировании. Именно этим вопросам посвящена настоящая работа.

Вопросам кадрового обеспечения органов местного самоуправления посвящены труды многих российских и украинских авторов.

Классик государственного управления Г. Атаманчук рассматривает основные факторы кадрового обеспечения государственного управления, к которым относит: территориальный - деление по территориальногосударственным образованиям и административно-территориальным единицам; социальный - вовлечение граждан в управленческие процессы через органы государственной власти и местного самоуправления; технический - использование информационных технологий; правовой - использование правовых рычагов воздействия; организационный - создание эффективных организационных 
структур; кадровый - вовлечение в управленческий процесс высококвалифицированных управленческих кадров [1].

По мнению украинского ученого В. Малиновского, кадровое обеспечение это часть кадровой политики, под которой он понимает - стратегию и тактику политического курса работы с кадрами, который определяет решение социальных задач и совершенствование системы профессионального обучения [2].

Также вопросами кадрового обеспечения органов местного самоуправления занимались такие ученые как: В. Аверьянов, Л.В. Адамская, И.Н. Воронин Т. Кагановская и др.

Кадровое обеспечение при решении задач, обусловленных необходимостью надлежащей реализации функций государства со стороны органов местного самоуправления, фактически имеет четко выраженный управленческий характер и поэтому присуще всем формам такой деятельности.

Оно представляет собой целенаправленное воздействие соответствующего субъекта, наделенного государственно-властными полномочиями на объекты с целью упорядочения, организации и практического обеспечения деятельности системы местного самоуправления. Кадровое обеспечение влияет на эффективную работу организационных структур местного самоуправления с помощью квалифицированных кадров, способных решать вопросы регионального менеджмента.

Анализируя состояние кадрового обеспечения органов местного самоуправления г. Донецка, можно выявить ряд недостатков, которые существенно ухудшают процесс реализации труда и обеспечения интересов населения со стороны местной власти. Это непосредственно влияет на уровень жизни населения и положительные тенденции развития эффективной местной власти вообще. Поэтому выявление и нейтрализация этих проблем помогут повысить уровень социальной обеспеченности и благосостояния населения г. Донецка.

Вопрос кадрового обеспечения органов местного самоуправления должен регулироваться отдельным институтом регионального менеджмента институтом службы в органах местного самоуправления.

Сейчас процедурные вопросы кадрового обеспечения органов местного самоуправления регулируются Законом Донецкой Народной Республики «О системе государственной службы Донецкой Народной Республики» от 3 апреля 2015 года [3].

Однако в Законе отсутствует уточнение относительно службы в органах местного самоуправления. Например, можно ввести такое уточнение: «Служба в органах местного самоуправления - это профессиональная, на постоянной основе деятельность граждан ДНР, которые занимают должности в органах местного самоуправления, направленная на реализацию территориальной общиной своего права на местное самоуправление и отдельных полномочий органов исполнительной власти, предоставленных законом». 
Среди актуальных проблем кадрового обеспечения органом местного самоуправления г. Донецка можно выделить следующие:

- $\quad$ несовершенная нормативно-правовая база, которая бы регулировала организацию работы органов местного самоуправления, в частности отсутствие в законодательстве четких механизмов реализации полномочий органами местного самоуправления;

- неурегулированность статуса должностных лиц органов местного самоуправления, обусловленная необходимостью принятия законодательного акта о местном самоуправлении (в современных условиях существует только Закон ДНР «О местных выборах Донецкой Народной Республики» № 01-ІНС от 28.11.2014 [4];

- $\quad$ низкий уровень предоставления услуг в социальной сфере (охрана здоровья, образование, наука и т.п.), обусловленный недостаточным уровнем бюджетного обеспечения и финансирования делегированных полномочий органов местного самоуправления;

- низкий уровень заинтересованности и непосредственного участия граждан в решении вопросов локально-регионального значения и реализации права на контролирующие действия по независимому выполнению должностных полномочий служащими органов местной власти;

- низкий престиж службы в органах местного самоуправления, местных органах исполнительной власти, связанный с низким уровнем социальной защиты работников указанной сферы,

- несовершенство системы оплаты труда (отсутствие связи должностного оклада с уровнем квалификации, профессиональной подготовкой, отсутствие прозрачной системы премирования).

Таким образом, решение имеющихся проблем требует создания Стратегии кадрового обеспечения органов публичной власти ДНР, которая поможет реформировать систему подготовки кадров для органов публичной власти, что повлечет повышения уровня профессионализма и компетенции государственных служащих при решении важных вопросов благосостояния граждан г. Донецка и всей Донецкой Народной Республики. 


\section{Литература}

1. Атаманчук, Г.В. Теория государственного управления: курс лекций [текст] / Г.В. Атаманчук. - М.: Юридическая литература, 1997. - С. 380-384.

2. Малиновський, В. Державне управління: Навч. посіб. [текст] / В. Малиновський. Луцьк: Вежа, 2000. - С.54-55.

3. Закон ДНР «О системе государственной службы Донецкой Народной Республики» ГЭлектронный ресурс] от 03.04.2015 № 32-IHC. - Режим доступа: http://dnrsovet.su/zakon-dnr-o-gos-sluzhbe/

4. Закон ДНР «О местных выборах Донецкой Народной Республики» ГЭлектронный ресурсך от 28.11.2014 № 01-IHC. - Режим доступа: http://dnrsovet.su/zakon-dnr-o-gossluzhbe/ 